\title{
FLUNETS: A NEW MATLAB-BASED TOOL FOR DRAINAGE NETWORK ORDERING BY HORTON AND HACK HIERARCHIES
}

\author{
Candela PASTOR-MARTÍN ${ }^{1}$, Loreto ANTÓN ${ }^{1}$, Carlos FERNÁNDEZ-GONZÁLEZ ${ }^{2}$
}

DOI: 10.21163/GT_2018.132.09

\begin{abstract}
:
This work presents FLUNETS (FLUvial NETwork Sorting tool), a new MATLAB-based tool designed for channel network ordering by Horton and Hack hierarchies. Differently to Strahler and Shreve hierarchies, Hack and Horton orderings allow organizing a drainage network in a hierarchy, identifying the parent segment over the child segment, giving as a result a network where the value of a river remains unchanged from the mouth upstream to the headwater. The novelty of FLUNETS is that it allows the user to choose the hierarchy attribute. Therefore, a fluvial network can be ordered by distance to the mouth or by accumulation upstream. In addition, FLUNETS offers a wide set of optional parameters, which turns it into a friendly tool to attain a highly tailored ordered fluvial network. A continuous fluvial network is the starting point for multiple landscape analysis applications. The source code is available in the authors' GitHub account (https://github.com/geouned/FLUNETS).
\end{abstract}

Key-words: Hydrology, Fluvial hierarchies, Channel network, Horton, Hack, Geomorphology.

\section{INTRODUCTION}

In the last three decades advances in modelling Earth's surface have been made due to the development of algorithms and computer simulation models (e.g. Refice et al., 2012). Land surface analysis, hydrogeology assessment, drainage network analysis, etc., they all had an extensive development since the 1980s (Jenson, 1985, O'Callaghan and Mark, 1984), and keep developing today (Schwanghart and Kuhn, 2010, Jasiewicz and Metz, 2011). Regarding hydrology analysis, many flow-related algorithms have been developed, such as flow direction (Lindsay, 2003, O'Callaghan and Mark, 1984), flow accumulation, flow length, stream order, among others. In addition, numerous geomorphologic indices and other quantitative analysis based on the fluvial network have been developed. These indices provide information on landscape evolution (Antón et al., 2014, Tucker and Hancock, 2010, Whipple K.X. et al., 2003, Daxberger et al., 2014, Pastor-Martín et al., 2017b). Based on streams characterization, those analysis help to understand fluvial systems and landscape responses to external drivers such as climate, tectonics, human actions, etc. (Antón et al., 2012, Font et al., 2010, Pedrera et al., 2009, Johnson and Finnegan, 2015, Scherler et al., 2016, Shugar et al., 2017).

Most of the flow-related algorithms are implemented in Geographic Information System (GIS) software and have been developed for non-spatial software, such as MATLAB (MathWorks, 2012) or Octave (Eaton et al., 2014). Regarding channel network

\footnotetext{
${ }^{1}$ Universidad Nacional de Educación a Distancia (UNED), Dpto. de Ciencias Analíticas / Facultad de Ciencias, Senda del Rey 9, 20840 Madrid,Spain, cpastor@pas.uned.es; lanton@ccia.uned.es; ${ }^{2}$ Universidad Nacional de Educación a Distancia (UNED), Dpto. de Física Interdisciplinar / Facultad de Ciencias, Senda del Rey 9, 20840 Madrid, Spain, cafernan@ccia.uned.es;
} 
ordering algorithms, the majority of GIS software offers only topological network orderings, based on joining segments, such as Strahler or Shreve orderings. These systems provide single segments between junctions but not complete streams. To approach many studies related to geomorphology or hydrology, it is necessary to start the study from the extraction of a continuous fluvial network, in which each stream is identified as a complete river. Therefore, other channel network hierarchies are required, such as Horton and Hack. Hack and Horton hierarchies provide a continuous channel network, where the river value remains unchanged from the mouth up to the headwater. These two hierarchies ease to tackle stream long profile analysis (for example Jiménez-Cantizano et al., 2017, PastorMartín et al., 2017a) and most geomorphic indices calculations.

Attaining a suitable channel network for landscape analysis is still a challenge. The aim of this paper is to present FLUNETS, a new tool for channel network ordering by Horton and Gravelius/Hack hierarchies. Relying on the set of MATLAB functions for relief analysis provided by TopoToobox (Schwanghart and Kuhn, 2010, Schwanghart and Scherler, 2014), FLUNETS is designed to address the construction of an ordered fluvial network. The wide set of parameters this tool offers turns it into a very suitable tool for the correct extraction of a continuous channel network from a Digital Elevation Model (DEM) that serves as the starting point for multiple terrain analysis. Finally, we present the functionality with a case study investigating the channel network in the Pisuerga watershed, in the Iberian Peninsula.

\section{FLOW-RELATED CONCEPTS}

\subsection{Fluvial concepts}

Flow refers to a natural watercourse that goes from one place to another. Normally a fluvial network can be idealized as a planar tree where a channel is a branch and the master channel is the tree trunk. The furthest point downstream is the channel network outlet or mouth. Points furthest upstream are called stream heads or headwaters. The points where two channels join are called junctions or confluences.

\subsection{Drainage network ordering}

Drainage network ordering refers to the method to sort a channel network. There are multiple methods to order a drainage network. The most common ordering methods included in conventional GIS software are Strahler method (Strahler, 1957) (Fig. 1.A) and Shreve method (Shreve, 1967) (Fig. 1.B). In addition to these sorting hierarchies, there are other network orderings, such as original Horton hierarchy (Horton, 1945) (Fig. 1.C) and normal stream hierarchy proposed by Gravelius (1914) also known as Hack's main streams (Hack, 1957) (Fig. 1.D).

The main difference between the above mentioned sorting methods relies on that for Horton and Hack hierarchies the network is sorted from the mouth upstream direction until finding the headwaters. In contrast, Strahler and Shreve methods sort the channel network from the headwaters downstream towards the mouth.

Strahler remains to an idealized topological model, where the stream order changes from the watershed mouth point up to the stream head (Strahler, 1957). The smallest fingertip tributaries are designated with order 1 . When two segments of the same order $n$ join, a segment of order $n+1$ is formed. When two segments of different order meet, they form a segment of maximum order of both (Fig. 1.A). The master stretch is therefore the segment of highest order. Shreve hierarchy is similar to Strahler hierarchy. Fingertip 
segments are of order 1. When two segments join, the resultant segment downstream order is the sum of the segments' order joining. Hence, the magnitude of a segment is equal to the total number of stream heads ultimately tributary to it (Shreve, 1967) (Fig. 1.B). Both hierarchies, Strahler (1957) and Shreve (1967) are purely topological hierarchies, where the interconnected segments between junctions do not involve lengths, shapes, accumulation rates or orientations of the segments comprising the channel network.

In contrast, Gravelius proposed one of the first attempts to classify drainage networks on the basis of branching (Gravelius, 1914, Hack, 1957). Starting from the watershed outlet, the main stream is designated as order 1 and smaller tributary streams are designated with increasingly higher orders, from the stream confluence upstream to the headwaters. When a parent channel of order $n$ meets a junction, ascribes order $n+1$ to the joining tributary (Fig. 1.D). On the contrary, Horton considered that the main stream should be the one with the highest order and that unbranched fingertip tributaries should always be designated as order 1 . Tributaries of second order receive only tributaries of first order, third order tributaries receive tributaries of second order but may also receive first order tributaries, and so on (Horton, 1945) (Fig. 1.C). To determine which the parent segment is and which is the child segment in a junction, Horton considers that the stream that forms the greatest angle with the parent is of lower order. If both joining streams form the same angle with the parent, the shorter stream is taken as of the lower order.
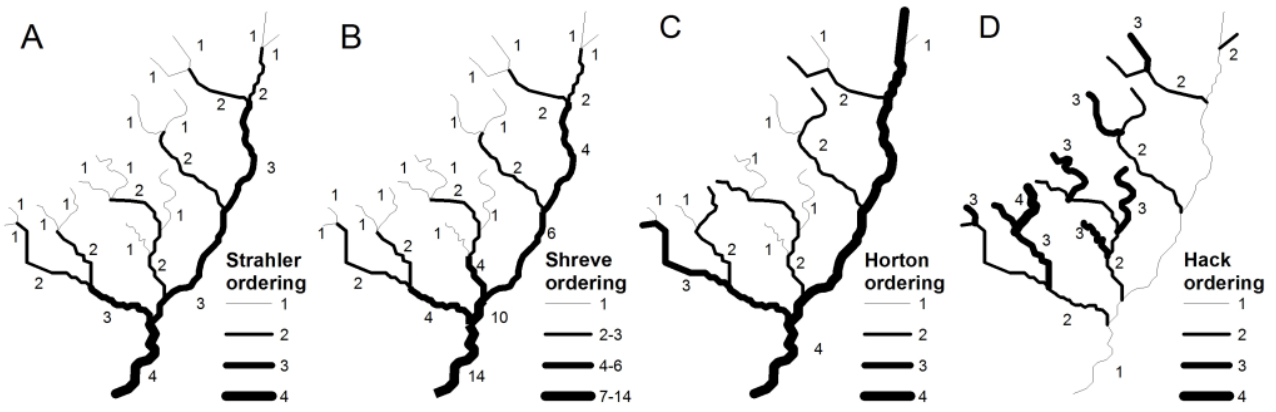

Fig. 1. Stream network orderings: (A) Strahler (Strahler, 1957), (B) Shreve (Shreve, 1967), (C) Horton (Horton, 1945), (D) Hack (Hack, 1957).

\section{METHODOLOGY}

FLUNETS relies on TopoToolbox 2 (Schwanghart and Kuhn, 2010, Schwanghart and Scherler, 2014), thus it requires download the set of functions freely available on the authors' webpage (physiogeo.unibas.ch/topotoolbox). Technical requirements for its use are explained in detail in the user guide and readme files available on the author's GitHub repository (https://github.com/geouned/FLUNETS).

\subsection{Tool-related concepts}

In this tool, the furthest point downstream of the channel network is called outlet. The point where two channels join is called confluence and the point before the cell where two channels converge is called pour point. 


\subsection{Parameters}

FLUNETS requires setting a set of mandatory and optional input parameters prior to its execution. Mandatory parameters are the following: (i) selecting the DEM file. This can be an ASCII or TIFF/GeoTIFF file; (ii) the sorting method: Horton or Hack and (iii) the hierarchy attribute which defines the hierarchy of a segment over another when two or more segments converge in a confluence. It can be upstream accumulation or upstream distance.

If two channels have the same hierarchy attribute value at the pour point, elevation is compared as a second parameter. In such case, the branch with lowest elevation at the pour point will be given the highest order (Jasiewicz and Metz, 2011). Upstream accumulation and upstream length replace Horton's previous idea to give the greatest order to the branch that has a smaller angle with respect to the parent branch (Horton, 1945). This idea was discarded because it resulted in unrealistic drainage structures (Ai, 2007).

\begin{tabular}{l} 
Sorting Method \\
hack \\
Hierarchy Attribute \\
\hline accumulation \\
Max. tributary order (optional) \\
\hline 1 \\
Min. drainage area (m^2) (optional) \\
\hline Max. base (optional) \\
\hline Calculate Internal fluvial files: (yes/no) (optional) \\
\hline \\
\hline Calculate Pour Points: (yesino) (optional) \\
\hline \\
\hline Output File extension: TIF or ASC (optional) \\
\hline asc \\
\hline
\end{tabular}

Fig. 2. FLUNETS user interface.

There is also a set of optional parameters. The aim of the optional parameters is to attain a more customized channel network to avoid the tedious steps of post processing the data, hence to provide a valid output to be the starting point for multiple terrain analysis. If these parameters are left empty, a default value for each of them will be set. The optional parameters are the following: (i) the maximum tributary order, which is the '-ith' order up to which the channel network will be sorted; (ii) the minimum drainage area, which refers to the minimum drainage area of a channel -at the pour point-; (iii) the maximum base level, which is the height an outlet must have to be considered. This parameter is useful to select only outlets located at a certain elevation; (iv) the pour points location and the flowrelated matrices can be provided as raster output files; (v) and finally, the raster format for the sorted channel network. It can be either ASCII or TIFF/GeoTIFF -in case of having the 
MATLAB Mapping Toolbox package installed, a GeoTIFF file can be generated for the TIFF option, else a normal TIFF file will be given-. The output channel network is also given as a CSV file. The CSV contains a record for each cell of each river sorted. The fields store the following information: the $\mathrm{x}$ and $\mathrm{y}$ coordinates for each cell (these coordinates represent the cell center), the height, the order (Hack's or Horton's), the accumulation, the accumulated drainage area in square meters, the river identifier, the distance downstream in meters, the pour points and the outlets of the network. Fig. 2 shows an example of the FLUNETS user interface.

\subsection{Extraction and sorting processes}

The internal process of this tool is shown in Fig. 3. The initial points are the outlets. From these points, the drainage network skeleton is performed in upstream direction, finding pour points along the river until reaching the head of the channels. These pour points will be the starting points to extract new channels of the network until reaching the headwaters.

A

FLUNETS_main() build_streams_map() build_channel_network() build_channel()
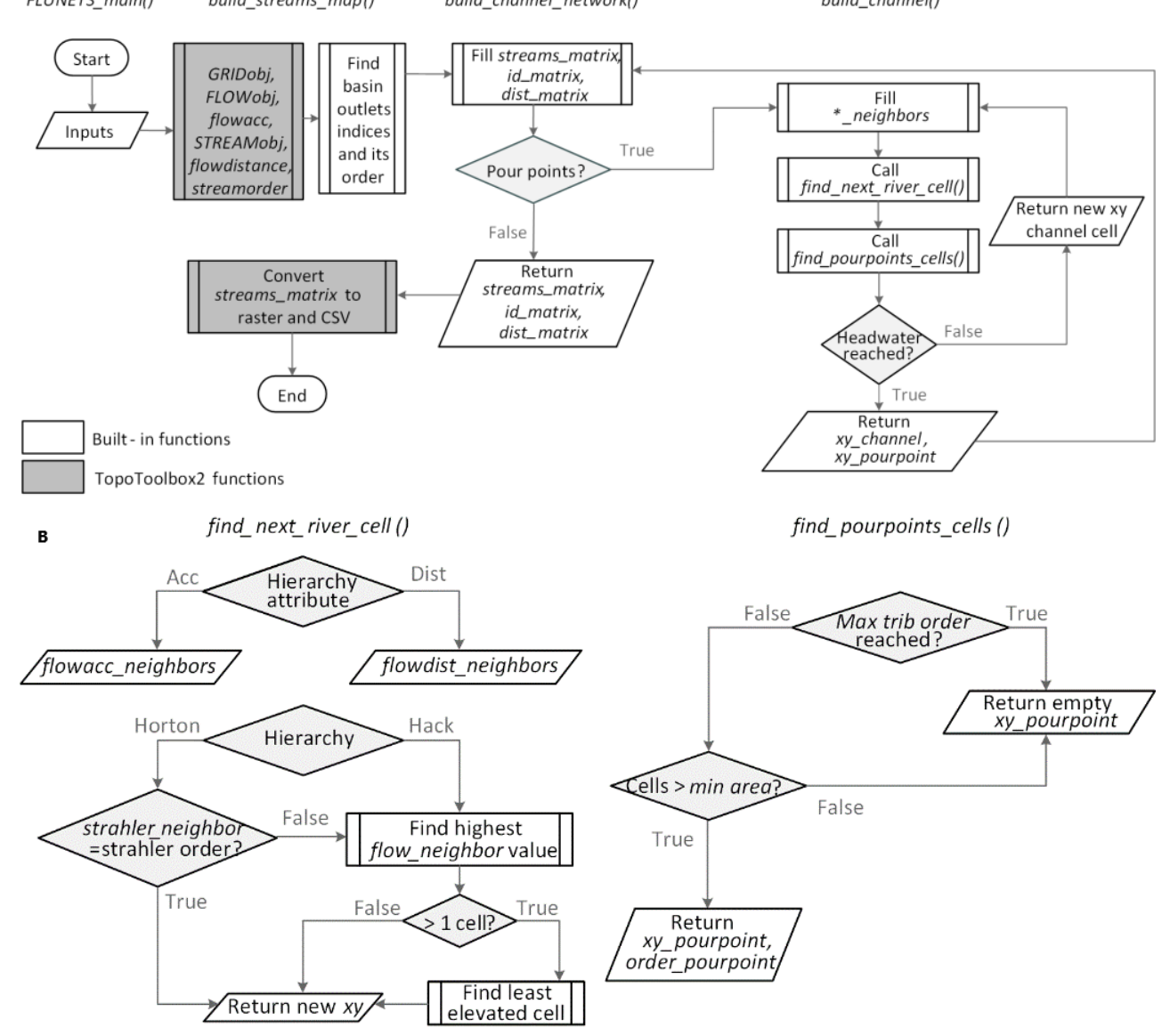

Fig. 3. Workflow of the processes for the extraction and ordering by Horton or Hack hierarchies. (A) Complete workflow. (B) Schemas of find_next_river_cell and find_pourpoints_cells functions. 
The first step is to compute the flow-related matrices. To initially generate the flowrelated matrices functions from the TopoToolbox 2 (Schwanghart and Kuhn, 2010, Schwanghart and Scherler, 2014) are applied. This is done in build_streams_map function, where the GRIDobj function reads the DEM file, FLOWobj generates the flow direction model from the DEM, flowacc calculates the accumulation model, STREAMobj and flowdistance compute a flow distance model and finally, if Horton is chosen as the hierarchy method, a Strahler model is created. Once this first step is achieved, the process of extracting a channel network begins. The build_channel function is responsible for extracting each single channel, from the pour point up to the headwater. The first channel cell to assess is the watershed outlet. To assess a channel cell, a $3 \times 3$ auxiliary window matrix is created around it (Fig. 4). Six empty arrays -named as *_neighbors in Fig. 3.Aare created, and each array is filled with neighboring cells values of the following matrices: elevation, flow direction, flow accumulation, flow distance, Strahler (only for Horton hierarchy) and neighbors' linear indices. When the auxiliary arrays are filled, find_next_river_cell function finds the neighbor that will become the next channel cell and, hence, the next cell to be addressed.

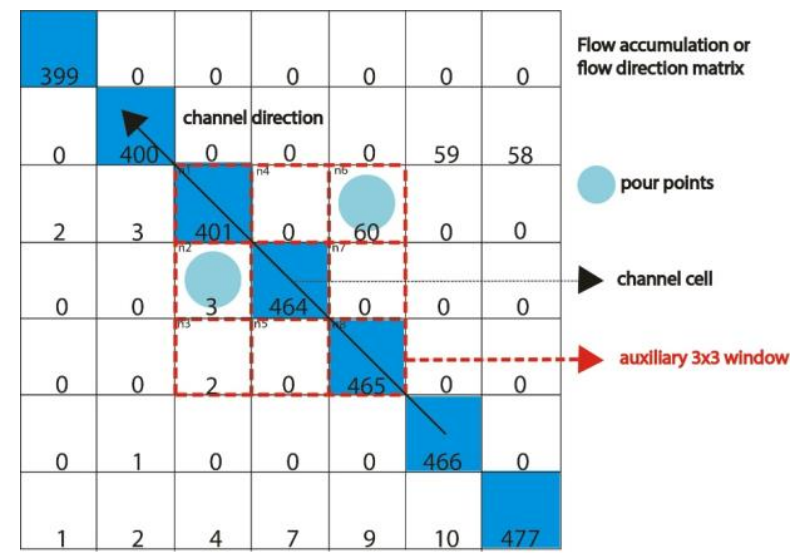

Fig. 4. Building a 3x3 auxiliary window around the channel cell to obtain the cell values of the eight neighbors from the DEM, flow direction, flow accumulation, flow distance and Strahler matrices and their linear indices. Values are stored in the arrays ending as "_neighbors".

The last step in the process is to identify the pour points that will become the initial cells to delineate tributaries. The find_pourpoints_cells checks the value set in the minimum watershed area parameter. Only the neighbors with equal or higher watershed area than the value set, except for the neighbor already identified as the next channel cell, will be stored as pour points (Fig. 3.B). The build_channel function continues to loop until it finds the headwater of the channel, which remains to the end of this channel. build_channel function returns $x y \_$channel and $x y \_$poipoint arrays, where the river cells and the pour points cells have been stored. Then starts looping over the newly found pour points to begin a new process of channels extraction. This process keeps on looping until the outputs are successfully generated. The CSV output file is filled with data from the *_matrix variables, which are auxiliary variables used during the stream network extraction 
process to store river cell values, such as elevation, accumulation upstream, distance to the mouth, etc.

\subsection{Case of study}

The case of study is located in the Pisuerga watershed (Fig. 5) in the Iberian Peninsula. Pisuerga river is $270 \mathrm{~km}$ in length with a watershed of $15,700 \mathrm{~km}^{2}$. Five of its main tributaries are Arlanza, Odra and Esgueva rivers, on the left side, and Carrión and Valdavia rivers, on the right side. The used DEM was taken from the Shuttle Radar Topography Mission (SRTM) (Rabus et al., 2003) version 4.1 of $90 \mathrm{~m}$ of spatial resolution.

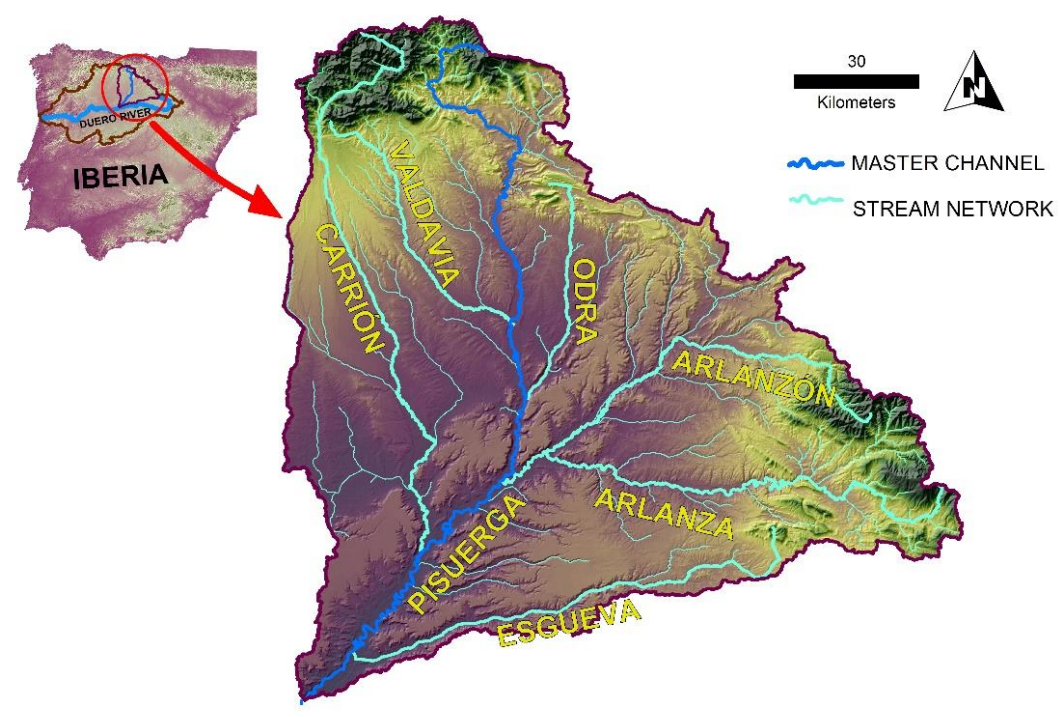

Fig. 5. Pisuerga basin SRTM v.4.1 DEM showing the master channel and main tributaries: Carrión, Valdavia, Odra and Esgueva rivers and the Arlanza-Arlanzón system.

FLUNETS was used to investigate the Pisuerga watershed. Table 1 shows the results of applying FLUNETS to the Pisuerga basin and the different parameters used. These output networks were filtered and the main first-order tributaries with a length over $80 \mathrm{~km}$ were selected. In addition, the Arlanzón river was added to the filtered networks, because some hierarchies have considered it as part of the main river (Fig. 6). The channel networks were equivalent to the tributaries of Carrión, Valdavia, Odra, Esgueva, Arlanza and Arlanzón recognized as main tributaries by the Confederación Hidrográfica del Duero (CHD) and by the Instituto Geográfico Nacional (IGN) (Fig. 6.E).

\section{RESULTS AND DISCUSSION}

The trajectories of the channels coincide with the channels provided by the CHD and IGN (Fig. 6). The cases in which the upstream distance was the hierarchy attribute, the river identified as the main channel follows the Pisuerga path recognized in the topographic 
maps of the IGN (Fig. 6.A and Fig. 6.C). In addition to this, in Hack hierarchy (Fig. 6.A), tributaries of Carrión, Valdavia, Odra, Esgueva and Arlanza were identified as first order tributaries, and Arlanzón river as second order tributary, resembling the CHD and IGN channel networks for the Pisuerga watershed (Fig. 6.E).

However, the two channel networks that were ordered by upstream accumulation (Fig. 6.B and Fig. 6.D), have identified Arlanzón river as part of the main river, turning the Pisuerga upper reach into a tributary of this one. In these two channel networks, Arlanzón river, accumulates more water at the pour point than Pisuerga upper reach.
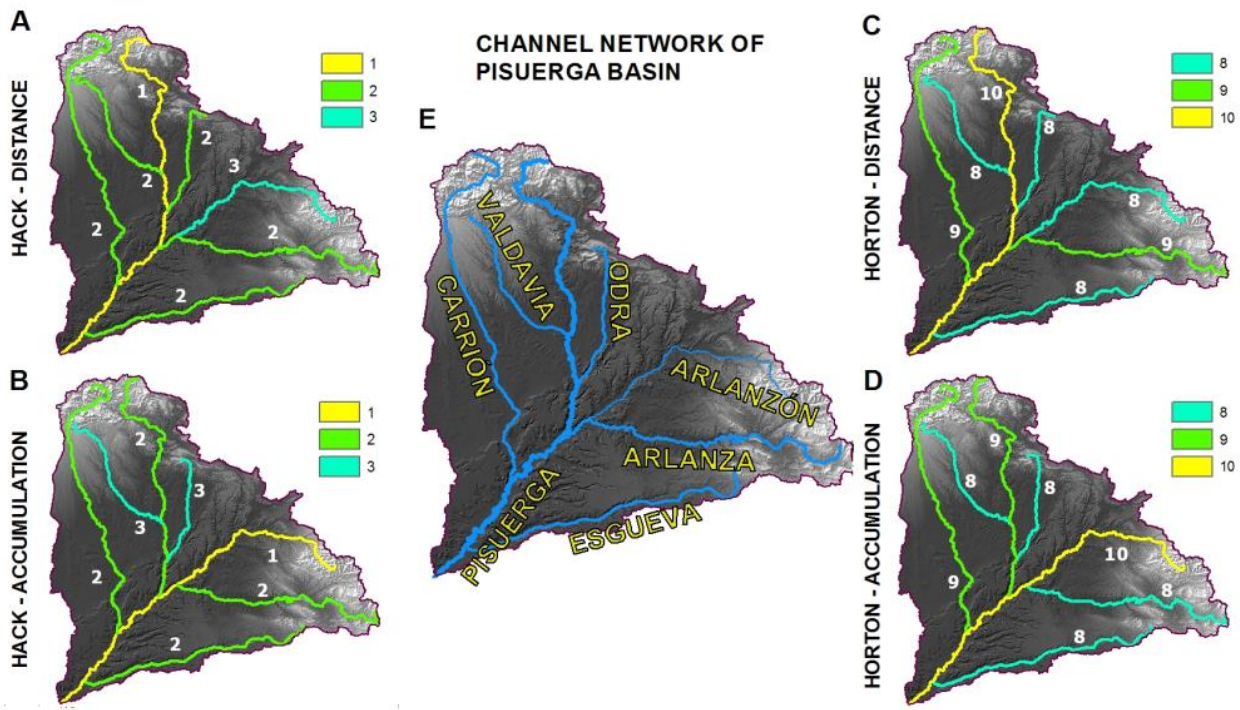

Fig. 6. The channels represented in the subfigures were obtained by filtering first order tributaries larger than $80 \mathrm{~km}$ in length for each channel network. In addition, the Arlanzón river was added to the filtered networks, because some of the hierarchies considered it as part of the main river. (A-D) Different combinations of the hierarchy method with the hierarchy attribute. (E) Official hydrological network from the CHD at 1: 50,000 scale.

Table 1: Results of FLUNETS applying different parameters.

\begin{tabular}{c|c|c|c|c|c|c|c|c|c}
$\begin{array}{c}\text { Sorting } \\
\text { type }\end{array}$ & $\begin{array}{c}\text { Hierarchy } \\
\text { attribute }\end{array}$ & $\begin{array}{c}\text { Max. } \\
\text { tributary } \\
\text { order }\end{array}$ & $\begin{array}{c}\text { Total } \\
\text { number } \\
\text { of } \\
\text { channels }\end{array}$ & $\begin{array}{c}\text { Number } \\
\text { of } 1^{\text {st }} \\
\text { order } \\
\text { tributaries }\end{array}$ & $\begin{array}{c}\text { Number } \\
\text { of } 2^{\text {nd }} \\
\text { order } \\
\text { tributaries }\end{array}$ & $\begin{array}{c}\text { Min. } \\
\text { channel } \\
\text { length } \\
{[\mathrm{m}]}\end{array}$ & $\begin{array}{c}\text { Max. } \\
\text { channel } \\
\text { length } \\
{[\mathrm{m}]}\end{array}$ & $\begin{array}{c}\text { Min. } \\
\text { order }\end{array}$ & $\begin{array}{c}\text { Max. } \\
\text { order }\end{array}$ \\
\hline Hack & Acc. & 2 & 997 & 158 & 838 & 1,409 & 243,335 & 1 & 3 \\
Hack & Dist. & 2 & 967 & 183 & 783 & 1,558 & 272,985 & 1 & 3 \\
Horton & Acc. & 2 & 993 & 164 & 828 & 1,409 & 247,335 & 3 & 10 \\
Horton & Dist. & 2 & 978 & 188 & 789 & 1,589 & 271,778 & 3 & 10
\end{tabular}

The combination of factors that in the past determined the hierarchy and the headwaters location of a drainage network varies depending on the place. These historical 
reasons determine the fluvial networks presented in nowadays-topographic maps. The drainage networks extracted using FLUNETS, may not totally agree with the channel's hierarchy presented in the topographic maps, although they represent a way to sort a continuous channel network that describes more realistically the topography. This is because depending on the parameter that is chosen as hierarchy attribute, the channel network will be sorted in a certain way according to the elevation values and the topography. Therefore, the hierarchy of the tributaries will be determined by the river extracted as master channel.

Nevertheless, FLUNETS provides a highly customized continuous channel network. Not only does FLUNETS provide a sorted channel network but also information about the drainage watershed from which it can be inferred other information such as the topography and geomorphology of the terrain.

In addition, a sorted network by one of these two hierarchies eases the following steps in the analysis of a watershed. For instance facilitates previous steps for the automation of geomorphological indices, such as Valley Height-Width Ratio (Vf), Stream LengthGradient Index (SL), basin asymmetry factor, etc., which require a continuous channel network previously extracted from the DEM. These indices give a more extensive knowledge of the characteristics and properties of a watershed, and the combination of these indices provides very significant information on fluvial morphology useful to understand landscape evolution in terms of tectonics, climate change or geomorphological processes.

\section{CONCLUSIONS}

In this paper, we present FLUNETS, a new MATLAB-based tool for drainage network sorting in a non-spatial environment. The tool offers two ordering hierarchies, Hack and Horton. This tool is applicable to any DEM. In this work, the tool was applied to the Pisuerga watershed, a subbasin of the Duero river, and the differences in the results derived from the different combination of parameter values support its robustness.

Up to our knowledge, nowadays no tool was available for non-spatial software that allowed the ordering of stream networks by Hack and Horton hierarchies. In addition to this, this tool allows choosing the hierarchy attribute to lead the sorting process, between upstream accumulation and upstream distance. Also, the high number of optional parameters enables to attain a highly tailored sorted drainage network that best suites the user's requirements, such as selecting the maximum order of tributaries instead of extracting a complete and dense channel network. The multiple information provided in the CSV file enable an in deep analysis of the channel network (longitudinal profiles extraction, length and ordering analysis and/or filtering, etc.) and facilitate the data management.

Horton and Hack hierarchies provide a continuous drainage network, as each channel retains the same value from its mouth up to the headwater. Unlike nodes graphs, this type of ordering eases the analysis of terrain properties that can be inferred from them. A channel network sorted by Hack or Horton hierarchies are necessarily the starting point for landscape evolution studies and terrain analysis, by the extraction of longitudinal profiles or the calculation of geomorphometric indices. 


\section{ACKNOWLEDGEMENTS}

This work was supported by Spanish Ministerio de Economía y Competitividad [PEJ-2014-A-93258]; Universidad Nacional de Educación a Distancia [GID2016-19]; MITE [CGL2014-59516-P] and CARESOIL [S2013/MAE-2739].

\section{R E F E R E N C E S}

AI, T. 2007. The drainage network extraction from contour lines for contour line generalization. ISPRS Journal of Photogrammetry and Remote Sensing, 62, 93103.

ANTÓN, L., DE VICENTE, G., MUÑOZ-MARTÍN, A. \& STOKES, M. 2014. Using river long profiles and geomorphic indices to evaluate the geomorphological signature of continental scale drainage capture, Duero basin (NW Iberia). Geomorphology, 206, 250-261.

ANTÓN, L., RODÉS, A., DE VICENTE, G., PALLÀS, R., GARCIA-CASTELLANOS, D., STUART, F. M., BRAUCHER, R. \& BOURLÈS, D. 2012. Quantification of fluvial incision in the Duero Basin (NW Iberia) from longitudinal profile analysis and terrestrial cosmogenic nuclide concentrations. Geomorphology, 165-166, 5061.

DAXBERGER, H., DALUMPINES, R., SCOTT, D. M. \& RILLER, U. 2014. The ValleyMorph Tool: An automated extraction tool for transverse topographic symmetry (T-) factor and valley width to valley height (Vf-) ratio. Computers \& Geosciences, 70, 154-163.

EATON, J. W., BATEMAN, D., HAUBERG, S. \& WEHBRING, R. 2014. GNU Octave version 3.8.1 manual: a high-level interactive language for numerical computations, CreateSpace Independent Publishing Platform.

FONT, M., AMORESE, D. \& LAGARDE, J.-L. 2010. DEM and GIS analysis of the stream gradient index to evaluate effects of tectonics: the Normandy intraplate area (NW France). Geomorphology, 119, 172-180.

GRAVELIUS, H. 1914. Flusskunde. Goschen Verlagshan dlug Berlin. Zavoianu, I.(1985): Morphometry of Drainage Bassins. Amsterdam, Elsevier.

HACK, J. T. 1957. Studies of longitudinal stream profiles in Virginia and Maryland, US Government Printing Office.

HORTON, R. E. 1945. Erosional Development of Streams and Their Drainage Basins; Hydrophysical Approach to Quantitative Morphology. Geological Society of America Bulletin, 56, 275.

JASIEWICZ, J. \& METZ, M. 2011. A new GRASS GIS toolkit for Hortonian analysis of drainage networks. Computers \& Geosciences, 37, 1162-1173.

JENSON, S. K. Automated derivation of hydrologic basin characteristics from digital elevation model data. Proc. Auto-Carto, 1985. 301-310.

JIMÉNEZ-CANTIZANO, F., ANTÓN, L., SORIA-JÁUREGUI, Á. \& PASTOR-MARTÍN, C. 2017. Cálculo del perfil teórico de equilibrio de un río en función del índice de gradiente. Geogaceta, 62.

JOHNSON, K. N. \& FINNEGAN, N. J. 2015. A lithologic control on active meandering in bedrock channels. Geological Society of America bulletin, 127, 1766-1776.

LINDSAY, J. B. 2003. A physically based model for calculating contributing area on hillslopes and along valley bottoms. Water Resources Research, 39, n/a-n/a. 
MATHWORKS 2012. Bioinformatics Toolbox: User's Guide (R2012a). http://www.mathworks.com/help/pdf_doc/bioinfo/bioinfo_ug.pdf.

O'CALLAGHAN, J. F. \& MARK, D. M. 1984. The extraction of drainage networks from digital elevation data. Computer vision, graphics, and image processing, 28, 323344.

PASTOR-MARTÍN, C., ANTÓN, L. \& FERNÁNDEZ-GONZÁLEZ, C. 2017a. Matlabbased tool for drainage network ordering by Horton and Hack hierarchies. Primer Congreso en Ingeniería Geomática, 1.

PASTOR-MARTÍN, C., ANTÓN, L. \& FERNÁNDEZ-GONZÁLEZ, C. Quantification in tectonic geomorphology: An ArcGIS Toolbox for the automatic extraction of the basin asymmetry index (Af). In: GEOMORFÓLOGOS, A. P. D., ed. $8^{\circ}$ Congresso Nacional de Geomorfologia, 4-7 October 2017b Oporto. 5-6.

PEDRERA, A., PÉREZ-PEÑA, J. V., GALINDO-ZALDÍVAR, J., AZAÑóN, J. M. \& AZOR, A. 2009. Testing the sensitivity of geomorphic indices in areas of low-rate active folding (eastern Betic Cordillera, Spain). Geomorphology, 105, 218-231.

RABUS, B., EINEDER, M., ROTH, A. \& BAMLER, R. 2003. The shuttle radar topography mission - a new class of digital elevation models acquired by spaceborne radar. ISPRS journal of photogrammetry and remote sensing, 57, 241262.

REFICE, A., GIACHETTA, E. \& CAPOLONGO, D. 2012. SIGNUM: A Matlab, TINbased landscape evolution model. Computers \& Geosciences, 45, 293-303.

SCHERLER, D., LAMB, M. P., RHODES, E. J. \& AVOUAC, J.-P. 2016. Climate-change versus landslide origin of fill terraces in a rapidly eroding bedrock landscape: San Gabriel River, California. Geological Society of America bulletin, 128, 12281248.

SCHWANGHART, W. \& KUHN, N. J. 2010. TopoToolbox: A set of Matlab functions for topographic analysis. Environmental Modelling \& Software, 25, 770-781.

SCHWANGHART, W. \& SCHERLER, D. 2014. Short Communication: TopoToolbox 2 MATLAB-based software for topographic analysis and modeling in Earth surface sciences. Earth Surface Dynamics, 2, 1-7.

SHREVE, R. L. 1967. Infinite topologically random channel networks. The Journal of Geology, 75, 178-186.

SHUGAR, D. H., CLAGUE, J. J., BEST, J. L., SCHOOF, C., WILLIS, M. J., COPLAND, L. \& ROE, G. H. 2017. River piracy and drainage basin reorganization led by climate-driven glacier retreat. Nature Geoscience, 10, 370-375.

STRAHLER, A. N. 1957. Quantitative analysis of watershed geomorphology. Eos, Transactions American Geophysical Union, 38, 913-920.

TUCKER, G. E. \& HANCOCK, G. R. 2010. Modelling landscape evolution. Earth Surface Processes and Landforms, 35, 28-50.

WHIPPLE K.X., WOBUS, C., KIRBY, E. \& SNYDER, N. P. 2003. Tectonics from topography: Methods, Application, and Limitations. AGU Fall Meeting Abstracts. 